\title{
University
}

Boeren, E. and Whittaker, S. (2018) A typology of education and training provisions for low educated adults: categories and definitions. Studies in the Education of Adults, 50(1), pp. 4-18. (doi:10.1080/02660830.2018.1520017)

There may be differences between this version and the published version. You are advised to consult the publisher's version if you wish to cite from it.

http://eprints.gla.ac.uk/197441/

Deposited on: 09 October 2019

Enlighten - Research publications by members of the University of Glasgow http://eprints.gla.ac.uk 


\section{A typology of adult education provisions for low educated adults: categories and definitions}

\section{ABSTRACT}

It is Europe's ambition to be a strong knowledge based economy. The European Commission recognises the role of lifelong learning in achieving this aim. However, exploring participation rates in post-compulsory learning, it is clear that access to education and training is unequally distributed in society. We know that participation rates vary by socioeconomic and socio-demographic groups, as well as by country. However, the role of education and training institutions in facilitating and enabling participation is less well known and deserves further in-depth attention. In order to fill this gap, we scrutinised definitions and categorisations of adult education provisions as published by the leading international organisations in the field of education and training. We paid specific attention to opportunities available for the lowest educated adults in society. Based on our review, we constructed a new typology consisting of seven categories for addition to the knowledge base and use in our own Horizon 2020 project. The categories are: (1) basic skills and basic education, (2) second chance education at upper secondary levels, (3) post-secondary VET, (4) apprenticeships, (5) training that forms part of Active Labour Market Policies, (6) workplace or job-related learning and (7) personal or social learning.

\section{INTRODUCTION}

This paper presents and discusses a new seven categories typology of adult education provisions available for the lowest educated adults in society. Participation statistics in the field of lifelong learning demonstrate that those with the lowest levels of qualifications, from the lowest socio-economic backgrounds and in the least knowledge intensive jobs do not strongly engage with adult education (see e.g. Desjardins et al., 2006; OECD, 2013). Apart from focussing on their individual characteristics, it is also important to shed more light on the education and training opportunities available to them. This is one of the aims of the EUR 2.5 million Horizon 2020 project ENLIVEN 'Encouraging Lifelong Learning for an Inclusive and Vibrant Europe' which focuses on broad aspects of lifelong learning policies, funding, participation and employment of mainly the younger and most vulnerable adults. Exploring 
determinants of participation, it is clear from a wide range of surveys that educational attainment is the top determinant (see Author, 2016). As such, in this part of the project, we were mainly interested in those who did not finalise secondary education or who did not have the starting qualifications to continue their educational pathways into tertiary education. It is generally perceived that these adults could benefit from participating in adult education, for example in order to improve their employability and their financial prospects (see e.g. Field, 2012; Laal \& Salamati, 2012). Empowerment, active citizenship and better health have also been recognised as benefits of educational participation in the international literature and in Europe. In recent years, the European Commission has strongly focussed on the need to evolve into a lifelong learning society in which adults are being able to catch up with the needs of the knowledge-intensive economy and to contribute to stronger levels of social inclusion (see e.g. Óhidy, 2008; Holford and Spolar, 2012; European Commission, 2011). As such, by 2020, at least 15 percent of the adult population should participate in at least one adult learning activity on a four weeks' basis and the number of school drop-outs leaving compulsory education without a qualification of secondary education should decrease as well. Progress towards these benchmarks are being carefully monitored based on statistics produced by the European Commission and the OECD (the Organisation for Economic Cooperation and Development) and form part of the strong 'governance by numbers' approach, which aims to put countries under pressure that underperform in the rankings to up their game (see Dehmel, 2006; Ioannidou, 2007; Lee, Thayer and Madyun, 2008; Grek, 2009). But as will be demonstrated below, in order for adults to participate in educational activities, high quality educational offers need to be available to them and a more in-depth understanding on the role of these providers is welcomed in order to understand how to support adults in a more efficient and effective way. As part of the ENLIVEN project, interviews will be conducted with low-education adult learners in Austria, Bulgaria, England, Estonia, Flanders, Italy, Scotland, Slovakia and Spain. Parallel research will be undertaken in Australia. We will focus on the barriers low-educated adults have overcome to participate, but also on the support mechanisms put in place by the educational institutions themselves. In order to have a clear overview of the different types of adult education provisions available to these adults, we have engaged in a review of definitions and categorisations of adult education provisions. A key component of our review was to have a clear categorisation in place of major types of providers who focus on the lowest educated adults in society. During our review, we observed that the major typologies are generic in nature, and are not specifically tailored towards the needs of adults experiencing disadvantaged because of their 
low-educated status. As such, we used our review exercise as an opportunity to construct a new typology of adult learning provisions for the lowest educated adults.

Before presenting and discussing the seven types, we provide a more detailed discussion on the role of educational provisions in generating lifelong learning participation. Afterwards, we discuss our methods of review in order to outline our analytical approach to the construction of the seven categories typology of lifelong learning provisions for low-educated adults.

\section{THE ROLE OF PROVISIONS IN ADULT EDUCATION PARTICIPATION}

Understanding why adults do or do not participate in educational activities is rather complex, but has been intensively studied by one of the authors of this paper (author reference). In fact, participation is the result of an interplay between the individual potential learner, the educational provisions available to him/her and the country context in which s/he lives. The Comprehensive Lifelong Learning Participation Model (see Figure 1) represents the interplay between these three levels through three 'cogs' which need to interact with each other.

\section{[SEE FIGURE 1 HERE]}

At the individual level, adults have their own socio-economic and socio-demographic characteristics and it is clear from the literature that participation in adult education is a Matthew effect (Nesbit, 2005; Desjardins, Rubenson and Milana, 2006; Brookfield, 2010; Evans, Schoon and Weale, 2013; Kaufmann and Widany, 2013; Kyndt and Baert, 2013). Those who have already accumulated education credentials, known to strongly relate with middle class dynamics, will obtain more of them, widening the gaps between working-class and middle-class adults even further. The engagement of highly educated adults in knowledge intensive jobs furthers their participation in adult education even more. Based on previous research findings, e.g. by Macionis (2013), Sheared, Johnson-Bailey, Colin, Peterson and Brookfield (2010), White (2012) and author (2018), we can also state that participation - especially in workplace learning - remains racialized and gendered, as women and adults from non-white backgrounds receive fewer lifelong learning opportunities, even when they are highly educated. At the same time, adults have their own behavioural characteristics as well, which tend to be influenced by their educational past. Adults who have been successful learners are more likely to be motivated to learn more, have gained a positive attitude towards learning and feel confident they will be able to finalise a course 
successfully (see e.g. Baert, De Rick and Van Valckenborgh, 2006). At the individual level, barriers encountered by adults can thus be dispositional, but also situational, e.g. when young parents feel discouraged to participate in an adult education course because of changed priorities and lack of time (Cross, 1981).

Evidence on the low participation rates of the lowest educated adults in society is clear, based on data from international surveys such as the Eurostat Adult Education Survey, the Labour Force Survey or data from the OECD's Programme for the International Assessment of Adult Competencies (author reference). However, while individual characteristics of adults, especially their educational attainment, largely predicts their (non-)participation, it is also important to recognise that educational provisions themselves can also act as strong institutional barriers or enablers, encouraging or preventing adults from engaging with educational activities . Unfortunately, this information on educational provisions is not strongly or only vaguely available in the existing datasets - as will be further explored below - and it is therefore important to devote more attention to the role of adult education provisions as important players in the generation of adult education participation. This is represented in the left upper cog of the Comprehensive Lifelong Learning Participation Model (see Figure 1). For example, we can refer to educational institutions in a formal or non-formal sense, but also to workplaces as generators of adult education activities. These learning providers can make it difficult to potential learners to access their courses if they offer their programmes in non-flexible modes, ask high enrolment fees or do not provide adults with learning routes adapted towards their needs in combining learning with work and family commitments (see e.g. Schuetze and Slowey, 2002). Similar mechanisms are in place at work (see e.g. Hefler and Markowitsch, 2008; Fuller and Unwin, 2011). Some employers are rather restrictive in the learning opportunities they offer to their employees, e.g. through only allowing them to develop themselves in relation to the specific job tasks they need to undertake. This is in contrast to the mode of operation of expansive working environments that put more focus on the development of general and transferrable skills. It is usually the lowest educated adults in the most elementary occupations who receive fewer opportunities for further participation. The provision of education and training activities is likely to happen in relation to the education policies available in the country and the availability of training initiatives is linked to the strength of the economy and the existence of active labour market policies (see Almeida and Aterido, 2008; Bassanini, Booth, Brunello, De Paola and Leuven, 2005; Brunello, 2001; Coulombe and Tremblay, 2007; Dammrich, Vono De Vilhena and 
Reichart, 2014; Groenez, Desmedt and Nicaise, 2007; Wolbers, 2005). This partly explains why participation rates in adult education are much higher in the social-democratic Scandinavian countries compared to e.g. in Southern European Mediterranean countries. Understanding the role of educational provisions in stimulating the uptake of adult education largely remains a black box in the international participation literature (see author). The first step in increasing knowledge in this area is to explore the availability of provision. As such, this paper is interested in answering the question on 'What typologies of educational provisions for adults are available in the literature?' and 'How far have these typologies focussed on the need for the lowest educated adults to further their education and training in adulthood?'

\section{METHOD OF REVIEW}

In better understanding the landscape of adult education and training provisions, we explored both the policy-oriented and academic literature in Europe. In relation to the policy-oriented literature, we focussed on key documents mentioning the importance of adult education as published by the OECD, the European Commission - including the Eurydice network and work by CEDEFOP, the European Centre for the Development of Vocational Training - and UNESCO. We also as explored codebooks of their surveys, more specifically PIAAC's Survey of Adult Skills, the Labour Force Survey, the Adult Education Survey and the Continuing Vocational Training Survey, in order to further understand the way in which adult learning activities are being defined. We started by exploring general definitions of lifelong learning, classifications of learning provisions in surveys and the policy-oriented literature as well as classifications being found in the academic literature. We used a documentary analysis technique in which documents were scrutinized for categorisations of educational provision. In the first instance, we explored general typologies and reported them in separate tables for comparison. In the second instance, we explored the focus on low-educated adults in the different categories available in the existing typologies. As typologies seem to be generic in nature, we decided to come up with a new seven categories typology of adult learning provisions available to the lowest educated adults in society. 


\section{EXISTING DEFINITIONS AND CATEGORISATIONS OF ADULT LEARNING}

\section{PROVISIONS}

\section{Definitions of lifelong learning}

Understanding what is exactly meant by 'lifelong learning' and what types of provisions are available in the field, we started to compare the definitions used by the international organisations. For the OECD (2007), lifelong learning refers to 'all purposeful learning activity, from the cradle to the grave, that aims to improve knowledge and competencies for all individuals who wish to participate in learning activities'. The indication of purposeful learning fulfilling certain aims was also found in the definition used by UNESCO (1984): 'All learning activity undertaken throughout life, with the aim of improving knowledge, skills and/or qualifications for personal, social and/or professional reasons'. Improving knowledge and skills has also been a central feature of the definitions adopted by the European Commission (2011) which focusses on 'all general education, vocational education and training, non-formal education and informal learning undertaken throughout life, resulting in an improvement in knowledge, skills and competences within a personal, civic, social and/or employment-related perspective'.

\section{Categorisations of adult learning provisions}

As can be seen from these definitions presented above, 'lifelong learning' is a rather broad concept, focussing on learning from cradle to grave, but also being life-wide in nature instead of simply being life-long. It refers to the well-known categories of learning into formal, nonformal and informal learning (Colley et al., 2003; Werquin, 2007). Generally speaking, formal learning refers to learning in formalised educational contexts which are credentialbased, non-formal learning takes place in organised settings as well, but is not credentialbased. Informal learning happens at random and is more likely to be non-intentional. As such, starting from an interest in types of educational provisions, we were mainly focussed on examples of formal and non-formal adult education, instead of focussing on informal types of lifelong learning. However, because of its broad focus, the distinction between formal, nonformal and informal is in fact not very helpful in furthering our understanding on the role of education and training providers in generating higher levels of participation.

Another way of understanding the different types of educational provisions available to adults is to explore how these are being conceptualised in the large scale surveys. As mentioned above, survey data are nowadays perceived as powerful policy-influencing tools. For the 
purpose of this review, we explored the codebooks of the PIAAC dataset, the Adult Education Survey, the Labour Force Survey and the Continuing Vocational Survey. We found that, in accordance with the discussion above, distinctions are being made between formal and non-formal learning activities. Formal learning is mostly further coded by ISCED levels, the International Standard Classification of Education, developed by UNESCO and widely used in the field, although not without certain levels of criticism of it being too vague, which we share (see e.g. Schneider, 2010). ISCED gives us an indication of whether the level of formal adult education attended is comparable to that of primary, upper or lower secondary or tertiary education, but can take place in a variety of types of provision, and thus needs to be further broken down. At the level of non-formal education, categories being used in the surveys are presented in Table 1. While there is thus a certain range of activities presented in survey data, it remains unclear in what type of education and training provisions these learning activities take place. It was therefore within our interest to further compare these with other existing classifications of educational provisions as produced by policy-oriented international organisations, going beyond the classic divide between formal, non-formal and informal.

\section{[TABLE 1 HERE]}

In reviewing, we scrutinized documents from the European Commission, the OECD and UNESCO to search for classifications. The leading classification seemed to be the one constructed by Eurydice, the European network exploring educational systems in Europe at all levels, ranging from pre-school education to adult education. In relation to adult education, the following types have been distinguished: (1) provision to raise achievement in basic skills, (2) provision to achieve a recognised qualification during adulthood, (3) provision targeting the transition to the labour market, (4) provision of liberal (popular) adult education and (5) other types of publicly subsidised provision for adult learners. While this classification is useful, the Eurydice focus is on publicly funded initiatives and this thus wipes out the role of adult education provision that takes place at work and other privately funded initiatives. Recent statistics from surveys indicate that workplace learning represents the largest part of the overall lifelong learning statistic (CEDEFOP, 2015; work by author) and an important focus on the increase of participation for non-traditional learners is on the need for employers to recognise the need to invest in education and training of their employees. Training targeting the labour market can be rather broad, e.g. a focus on apprenticeships, or a focus on specific funded programmes that take place in organisations 
through European funding streams like the Youth Guarantee Scheme. At the European level, the work by CEDEFOP (2008) also gives useful insights on the need to further diversify the role of labour market oriented provisions. They specifically focus on the role of accessible post-secondary VET for those who cannot continue into academic tertiary tracks, but who do possess the qualifications and skills to undertake post-secondary education. This seemed a meaningful further expansion of labour market training, to which we will be referring back to later on.

A few classifications were also found in the academic literature. Work by Myers et al. (2014) distinguished between (1) foundational learning, (2) higher education, (3) workplace-related learning, (4) other labour market-related learning and (5) personal/social learning. Desjardins (2017) used the following categorisations: (1) adult basic and general education, (2) adult higher education, (3) adult vocational education and (4) adult liberal education. These typologies were not constructed specifically to reflect on low-educated learners and therefore include categories like academic streams of higher education, which was beyond the scope of our classification review exercise. We also faced a need to further specify the vocational education components to reflect the problems faced by the fact that many low-educated adults in society face additional problems, such as unemployment or employment in low skill low pay jobs. A typology that has taken the diversification of vocational training more into account was published by Hefler and Markowitsch (2013) who distinguished between (1) basic skills and remedy programmes, (2) second chance education, (3) higher education programmes accessible for non-traditional (adult) students, (4) (occupational (re)training programmes, (5) costumised vocational and professional programmes for organisations, (post-tertiary) continuing higher education and (6) continuing professional education governed by professional bodies. This categorisation has been helpful, but, as intentionally, had a strong vocational focus, while our focus on lifelong learning is much broader, recognising the aim of lifelong learning for empowerment, social cohesion and active citizenship.

Having reviewed survey instruments, policy and academic-oriented literature, we can return to our initial questions and observe that categorisations of learning provisions are available, but that typologies do not specifically focus on low-educated adults. Some categories in the typologies do, however, none of the existing one provided a satisfactory categorisations for our target group. Therefore, we decided to present our own typology of learning provisions for low-educated adults. As explained above, these were defined as those who did not finalise 
secondary schooling or who lack starting qualifications to make the transition towards academic tracks of higher education.

\section{SEVEN CATEGORIES OF PROVISION FOR LOW-EDUCATED ADULTS}

Having carefully familiarised ourselves with the existing typologies as discussed above, and the need to focus on low-education adults, the following seven categories were included in the typology: (1) basic skills and basic education, (2) second chance education at upper secondary levels, (3) post-secondary VET, (4) apprenticeships, (5) training that forms part of Active Labour Market Policies, (6) workplace or job-related learning and (7) personal or social learning. An overview of the typology and the definition we constructed for each of the categories can be found in Table 2. We will now discuss each of the categories in detail and link back to how these are being defined by the leading policy-influencing organisations in the domain of education: UNESCO, the OECD and the European Commission.

[TABLE 2 HERE]

(1) basic skills and basic education

Basic skills and basic education is often linked to concepts like literacy and numeracy and the need for all adults to have at least a functional level of these skills, in order to successfully participate in and contribute to society. Especially literacy has been literacy has been central in this discourse, e.g. by UNESCO.

'Literacy is a key component of adult learning and education. It involves a continuum of learning and proficiency levels which allows citizens to engage in lifelong learning and participate fully in community, workplace and wider society. It includes the ability to read and write, to identify, understand, interpret, create, communicate and compute, using printed and written materials, as well as the ability to solve problems in an increasingly technological and information rich environment.' (Unesco Institute for Lifelong Learning, 2016a)

For the OECD, literacy is one of the core foci in their work on education through their worldleading international assessments such as PISA and PIAAC, which start from the need for every citizen to have a level of at least functional literacy in order to successfully contribute to society. Basic skills education can be perceived as a remedial programme that can help 
adults lacking these skills and is thus a vital component within a typology of lifelong learning provision that is specifically focussing on the most vulnerable adults in society.

'Literacy is the ability to identify, understand, interpret, create, communicate and compute, using printed and written materials associated with varying contexts. Literacy involves a continuum of learning in enabling individuals to achieve their goals, to develop their knowledge and potential, and to participate fully in their community and wider society' (OECD, 2016)

While the European Commission recognises the need for strong levels of numeracy and literacy in the current knowledge based society, it is also clear that basic education has to offer a broader curriculum and needs to be more than helping adults with writing and making basic calculations. It is here that it is important to compare with the range of skills young people learn at school and how these broad levels of skills and knowledge should also be incorporated into the Basic Education system, which is thus mainly formal in nature.

'Basic Education: Similar to 'basic skills' or literacy and numeracy, but suggesting a primary focus on education, and a broad curriculum rather than literacy and numeracy as skills' (National Research and Development Centre for Adult Literacy and Numeracy, 2008)

In the form of our own definition, we decided to make sure we kept in the broad focus on basic education in line with work by the European Commission. Therefore, basic education is a form of adult education provision that can help learners to prepare for elementary jobs, but also for active citizenship and future learning.

(2) second chance education at upper secondary levels

It is not always clear where basic skills education ends and second chance education starts. For the OECD for example, second chance education strongly aligns with basic education and can be interpreted in a broad way:

'Second chances for those who lack basic education and skills can be provided in a number of ways, including programmes that provide literacy training, work-based programmes, and arrangements to recognise informal learning.' (OECD, 2008) A more specific focus of second chance education, however, is on the credential-based programmes available for those who left school unqualified and who now want to return to 
obtain a final diploma of upper secondary education, widely regarded as they minimum level of qualification to be obtained in order to successfully function in society. It is also often perceived as the entrance qualification needed for entering tertiary education. This focus of second chance education is visible in documents produced by UNESCO.

'Education specifically targeted at individuals who, for a variety of reasons, never attended school or left school either before completion of the level of education in which they were enrolled or completed the level but wish to enter an education programme or occupation for which they are not yet qualified. Participants are often older than the typical target age group for the given ISCED level programme (but not necessarily adults). Sometimes also referred to as 'bridging programmes' or 'reintegration programmes' (Unesco UIS, 2011)

The European Commission does not seem to have a strong definition on the concept of second chance education despite having a dedicated website http://www.secondchanceeducation.eu/ which is mainly a space for teachers working in with adults Not in Employment, Education and Training (NEETs), providing some insight on their focus on vulnerable adults, as is the case in our own research project. As such, second chance education has been defined as being able to help adults obtain a qualification of upper secondary education so they can make the transition to tertiary education or employment at an intermediate skill level. Furthermore, increasing levels of education might boost adults' level of active citizenship.

(3) post-secondary VET

As our typology focuses on vulnerable adults, referring to those who do not qualify for progression to higher education or further academic tracks, we decided not to include tertiary education, but to include post-secondary VET as a separate category. First of all, it is important to focus on the definitions of VET used by the leading international organisations such as UNESCO, the OECD and the European Commission.

'technical and vocational education and training' (hereinafter "TVET”) is understood as comprising education, training and skills development relating to a wide range of occupational fields, production, services and livelihoods. TVET, as part of lifelong learning, can take place at secondary, post-secondary and tertiary levels and includes work-based learning and continuing training and professional development which may lead to qualifications. TVET also includes a wide range of 
skills development opportunities attuned to national and local contexts' (Unesco

Institute for Lifelong Learning, 2016b)

'Vocational education and training (VET) includes education and training

programmes designed for, and typically leading to, a particular job or type of job. It

normally involves practical training as well as the learning of relevant theory. It is

distinct from (academic) education' 'Initial VET includes programmes mainly

designed for and used by young people (we propose those under 30) at the beginning

of their careers and commonly before entering the labour market. It includes many

upper secondary and tertiary programmes.' (OECD, 2010)

'Vocational education and training, abbreviated as VET, sometimes simply called vocational training, is the training in skills and teaching of knowledge related to a specific trade, occupation or vocation in which the student or employee wishes to participate. Vocational education may be undertaken at an educational institution, as part of secondary or tertiary education, or may be part of initial training during employment, for example as an apprentice, or as a combination of formal education and workplace learning' (Eurostat glossary, accessed August 2017)

Vocational education is relevant in relation to vulnerable groups, especially in societies dominated by views that general/academic tracks are 'better' than vocational tracks. Some countries, e.g. the United Kingdom, do not have a strong tradition in relation to VET while others have, especially the German and Dutch speaking countries. However, even in these countries, vocational tracks are often perceived as less prestigious than the academic routes followed by students from mainly middle class backgrounds. Nevertheless, vocational education and training can help vulnerable young adults to master a range of skills and knowledge specifically targeted towards a specific job or type of employment as it moves away from the more general academic knowledge expected in non-vocational tracks. Postcompulsory vocational education and training can therefore act as an ideal pathway for those not ready to make the transition to traditional routes of higher education, but in need of some further education and training on top of the functional levels of skills provided in basic and second chance education.

(4) apprenticeships

While work-related education and training schemes were mentioned in previously published typologies, we felt it was needed to pay more detailed attention to the role apprenticeships 
can play in encouraging vulnerable adults to learn and find work. Apprenticeships are characterised by their alternation between formal schooling and participation and it can therefore be argued to need to be integrated in the vocational education and training category. We decided to have apprenticeships as a separate type of learning opportunities available for vulnerable adults in society as they seem to have a stronger primary basis in the employment sphere than the education sector. Employers and industry are meant to be at the heart of the apprenticeship system. Furthermore, European policy in the area of youth unemployment is strongly focussing on apprenticeship type interventions through e.g. the Youth Guarantee scheme.

As with the discussion of previous categories, we illustrate their meaning through engagement with definitions constructed by the leading international organisations, e.g. the International Labour Organisation, but also by the European Commission.

'Formal apprenticeship refers to a system by which a learner (the apprentice) acquires the skills for a trade or craft in an enterprise learning and working side by side with an experienced craftsperson, usually complemented by classroom-based instruction.' (ILO, 2012).

'...those forms of IVET that formally combine and alternate company based training with school-based education, and whose successful completion leads to nationally recognised IVET certification degrees' (European Commission, 2013)

As with VET in general, there are significant differences between how countries have set up their apprenticeship schemes, as outlined by the OECD.

'Apprenticeships often involve some form of blended on- and off-the-job training but the design is highly variable, ranging from the alternance arrangements in the dual system with apprentices attending school one or two days a week to the Norwegian arrangement with two years of school followed by two years of workplace training. For many countries apprenticeship represents a core element of initial VET, although this is highly variable between countries' (OECD, 2009a)

Despite the variation in the organisation of apprenticeship schemes in different European countries, definitions seem to agree that this type is an example of dual education and training which combines work experience with formal education with the aim to become a competent professional in a certain occupation. 
(5) training that forms part of Active Labour Market Policies

Similar to apprenticeships, training that forms part of ALMPs is work-related in nature, but does not necessarily alternate between formal schooling and work. This type of education and training is mainly designed to help the unemployed back into work, as well as groups of inactive people who want to re-enter the labour market. Furthermore, programmes might be designed for those at the risk of unemployment to help them making the transition to new employment.

UNESCOs definition of ALMPs focuses on the role employers can play in employing longterm unemployed adults and it is not uncommon for ALMPs to be targeted towards employers who are being stimulated to increase opportunities for the unemployed e.g. through job creation.

'A programme designed to increase the number of people in employment or to improve the employment prospects of a target group, e.g. by the payment of subsidies to businesses who take on longterm unemployed people' (UnescoUNEVOC/NCVER, 2009)

The OECDs work has also focussed on the nature of training in relation to employment as part of ALMPs, but also focuses on the need to have training in place for specific vulnerable groups who might experience more difficulties in accessing the labour market than others.

'This category includes spending on public employment services and administration, labour market training, special programmes for youth when in transition from school to work, labour market programmes to provide or promote employment for unemployed and other persons (excluding young and disabled persons) and special programmes for the disabled' (OECD Glossary of Statistical terms, accessed February 2017)

Relevant discussions have also taken place at the level of the European Commission. It is also worth noting that in some countries, training as part of ALMP might be compulsory, e.g. for those who receive unemployment benefits.

'Measures to help unemployed people back into work, including job placement services, benefit administration, and labour market intervention programmes such as training and job creation.' (European Commission/EACEA/Eurydice, 2015) 
Generally speaking, training as part of ALMPs has a clear work-related focus and is designed to help people getting (back) into work.

(6) workplace or job-related learning

It is less obvious to include workplace learning in a typology of provisions that focuses on the role of learning opportunities for the most disadvantaged adults in society. Participation statistics clearly demonstrate that those with low levels of qualifications and those in elementary or semi-skilled jobs receive fewer opportunities to participate in lifelong learning activities, especially those that are work-related (see author, 2016). Definitions of workplace learning are fairly standard, focussing on types of learning in the workplace, although the way in which this is being organised can vary hugely. Some employers are only willing to invest in training that is directly relevant to task to perform on the job while others are also open to offer training to increase employees' skills in general. In relation to vulnerable adults, it remains an open question about how much we can expect employers to invest in the general and transferrable skills of their employees, although from a social justice perspective, broader inclusion of this group in workplace learning is recommended.

'Learning which takes place on site in the workplace, which can be statutory (e.g. health and safety), occupational and related to specific jobs, or wider programmes such as literacy, numeracy and language'. (National Research and Development Centre for Adult Literacy and Numeracy, 2008)

'The process of learning through experience at the workplace, both formally and informally, and through different forms of working arrangements, such as teams or one-to-one. Also the creation of a learning environment in the workplace.' (UnescoUNEVOC/NCVER, 2009).

(7) personal or social learning

Many of the categories above have a clear work-related focus. While this is in line with the focus on adult lifelong learning by leading international organisations (see Holford \& Mohorcic-Spolar, 2012), it is important to underline that lifelong learning can also be used for personal development. This has been underlined by UNESCO.

'Adult learning and education also includes education and learning opportunities for active citizenship, variously known as community, popular or liberal education. It empowers people to actively engage with social issues such as poverty, gender, 
intergenerational solidarity, social mobility, justice, equity, exclusion, violence, unemployment, environmental protection and climate change. It also helps people to lead a decent life, in terms of health and wellbeing, culture, spirituality and in all other ways that contribute to personal development and dignity.' (Unesco Institute for Lifelong Learning, 2016a)

Traditionally, as outlined in the UNESCO definition, the term 'liberal' education has been used to focus on non-vocational and non-formalised types of education. Again, as pointed out with some of the other types of education and training, the way in which personal and social learning is organised in the different member states varies, as recognised by the European Commission.

'There is no standard definition of the term 'liberal adult education'. However, the concept commonly refers to courses that have a non-formal character and provide opportunities for personal development, cultural enrichment, and intellectual or creative stimulation and enjoyment. Liberal (or popular) adult education is sometimes seen in an opposition to professional and vocational education that prepares students for their future careers. However, the relationship between liberal and vocational education is more complex. In several European countries with a strong liberal adult education tradition (particularly the Nordic countries, but also the English speaking countries, where it is known as community learning/education), courses can lead to recognised qualifications.' (European Commission/EACEA/Eurydice, 2015)

While work-related forms of education and training are important, it is thus also vital to provide learning opportunities for personal and social development from which vulnerable adults can profit in relation to personal growth and the increase of their own active citizenship. It was therefore judged to be important for inclusion in our typology.

\section{DISCUSSION AND CONCLUSION}

Having outlined our seven categories typology of education and training provisions available for disadvantaged adults in society, together with their underlying definitions constructed by leading organisations, it is important to provide some critical comments as well as to outline how this typology will be used in further research. 
First of all, as with most typologies constructed in social sciences, a strict categorisation of lifelong learning provisions is somewhat artificial and it can be argued that some of the categories we defined can be taken together. A clear example includes the focus on vocational education and training and apprenticeships which might interrelate with each other in certain country contexts. However, in light of our focus on the most vulnerable adults in society, we preferred to distinguish between the different types as clearly as possible in order to make our audience aware of the different schemes that are available for our target group, who is much in need of attention from policy makers and society alike. Going back to the earlier sections of this paper, we criticised the lack of specific categorisations for vulnerable adults, such as e.g. the one constructed by Eurydice, and it was our aim to not lose this specific focus out of our review exercise.

Secondly, as mentioned above, we see this typology as a contribution to the knowledge base on lifelong learning provisions tailored towards the most vulnerable adults in society, but also as an exercise we had to engage with in order to proceed onto the next phase of our own Horizon 2020 research. In further understanding the experiences of vulnerable adult learners themselves, we need to have a structural frame in place from which we can sample in a range of European countries. Based on a comparative method, it is important to understand the role of education and training provisions in different countries embedded in their historical, political, economic and social context (see Bereday, 1964) and from there onwards to understand the experiences of both adult learners themselves, but also to further disentangle how adult educators and education and training managers in these institutional settings aim to facilitate the learning of these vulnerable adults. As explained above, participation in adult education is the result of an interaction between the individual learners, the education and training institutions they participate in and the way in which the different countries are regulating these provisions and stimulating adults themselves. It is these multilevel way of thinking that will be a guiding principle in the empirical part of our work package on adult learners' experiences. Results of these further tasks of our project will be reported in future papers.

\section{REFERENCES}

Almeida, R., \& Aterido, R. (2008). The incentives to invest in job training: do strict labor codes influence this decision? Washington: World Bank.

Baert, H., De Rick, K., \& Van Valckenborgh, K. (2006). Towards the conceptualization of 
'learning climate'. In R. Vieira de Castro, A. V. Sancho \& P. Guimaraes (Eds.), Adult education: new routes new landscapes (pp. 87-111). Braga: University de Minho.

Bassanini, A., Booth, A., Brunello, G., De Paola, M., \& Leuven, E. (2005). Workplace training in Europe. Bonn: Institute for the Study of Labour.

Bereday, G. (1964). Comparative method in education. New York: Holt, Rinehart \& Winston.

Brookfield, S. D. (2010). Theoretical frameworks for understanding the field. In C. E. Kasworm, A. D. Rose \& J. M. Ross-Gordon (Eds.), Handbook of adult and continuing education (pp. 71-81). Thousand Oaks: SAGE.

Brunello, G. (2001). On the complementarity between education and training in Europe. Bonn: IZA.

Cedefop. (2008). Terminology of European education and training policy: a selection of 100 key terms. Luxembourg: Cedefop.

Cedefop. (2015b). Unequal access to job-related learning: evidence from the adult education survey: Cedefop research paper No 52. Luxembourg.

Colley, H., Hodkinson, P., \& Malcolm, J. (Cartographer). (2003). Informality and formality in learning: a report for the Learning and Skills Research Centre.

Coulombe, S., \& Tremblay, J.-F. (2007). Explaining cross-country differences in job-related training: macroeconomic evidence from OECD countries. Économie internationale, 110(1), 5-29.

Cross, K. P. (1981). Adults as learners: increasing participation and facilitating learning. San Francisco: Jossey-Bass.

Dammrich, J., Vono de Vilhena, D., \& Reichart, E. (2014). Participation in adult learning in Europe: the impact of country-level and individual characteristics. In H.-P. Blossfeld, E. Kilpi-Jakonen, D. Vono de Vilhena \& S. Buchholz (Eds.), Adult learning in modern societies: an international comparison from a life-course perspective (pp. 2955). Cheltenham: Edward Elgar.

Dehmel, A. (2006). Making a European area of lifelong learning a reality? Some critical reflections on the European Union's lifelong learning policies. Comparative Education, 42(1), 49-62.

Desjardins, R. (2017). Political economy of adult learning systems comparative study of strategies, policies and constraints. London: Bloomsbury.

Desjardins, R., Rubenson, K., \& Milana, M. (2006). Unequal chances to participate in adult learning: international perspectives (No. null). Paris: UNESCO.

European Commission. (2011). Council resolution on a renewed European agenda for adult learning (No. 2011/C 372/01.). Brussels: European Commission.

European Commission. (2013). Apprenticeship and traineeship schemes in EU27: key success factors: a guidebook for policy planners and practitioners. Luxembourg: European Commission.

European Commission/EACEA/Eurydice. (2015). Adult education and training in Europe: widening access to learning opportunities. Luxembourg.

Eurostat. Education and training glossary. Retrieved 21 August, 2017, from http://ec.europa.eu/eurostat/statisticsexplained/index.php/Category:Education_and_training_glossary

Evans, K., Schoon, I., \& Weale, M. (2013). Can lifelong learning reshape life chances? British Journal of Educational Studies, 61(1), 25-47.

Field, J. (2012). Is lifelong learning making a difference? Research-based evidence on the impact of adult learning. In D. Aspin, J. Chapman, K. Evans \& R. Bagnall (Eds.), Second International Handbook of Lifelong Learning (pp. 887-897). Dordrecht: Springer. 
Fuller, A., \& Unwin, L. (2011). Workplace learning and the organization. In M. Malloch, L. Cairns, K. Evans \& B. N. O'Connor (Eds.), SAGE handbook of workplace learning. Thousand Oaks: SAGE.

Grek, S. (2009). Governing by numbers: the PISA 'effect' in Europe. Journal of Education Policy, 24(1), 23-37.

Groenez, S., Desmedt, E., \& Nicaise, I. (2007). Participation in lifelong learning in the EU15: the role of macro-level determinants. Paper presented at the European Conference for Education Research. Retrieved from https://www.academia.edu/attachments/3248407/download_file?st=MTUwMjcyMjIx NCwxOTQuODEuMjQ1Ljg2LDQyNzI2MjY5\&s=swp-toolbar

Hefler, G., \& Markowitsch, J. (2008). To train or not to train: explaining differences in average enterprises' training performance in Europe: a framework approach. In J. Markowitsch \& G. Hefler (Eds.), Enterprise training in Europe: comparative studies on cultures, markets and public support initiatives (pp. 23-60). Vienna: Lit Verlag.

Holford, J., \& Spolar, V. A. M. (2012). Neoliberal and inclusive themes in European lifelong learning policy. Lifelong Learning in Europe: Equity and Efficiency in the Balance, 39-61.

ILO. (2012). Upgrading informal apprenticeship: a resource guide for Africa. Geneva: International Labour Office (ILO), Skills and Employability Department (SED).

Ioannidou, A. (2007). A comparative analysis of new governance instruments in the transnational educational space: a shift to knowledge-based instruments? European Educational Research Journal, 6(4), 336-347.

Kaufmann, K., \& Widany, S. (2013). Berufliche Weiterbildung - Gelegenheits- und Teilnahmestrukturen. Zeitschrift für Erziehungswissenschaft, 16(1), 29-54.

Kyndt, E., \& Baert, H. (2013). Antecedents of employees' involvement in work-related learning: A systematic review. Review of Educational Research, 83(2), 273-313.

Laal, M., \& Salamati, P. (2012). Lifelong learning: why do we need it? Procedia: Social and Behavioral Sciences, 31(2012), $399-403$.

Lee, M., Thayer, T., \& Madyun, N. i. (2008). The evolution of the European union's lifelong learning policies: an institutional learning perspective. Comparative Education, 44(4), 445-463.

Macionis, J. J. (2013). Sociology. Cambridge: Pearson Publishers.

Myers, K., Conte, N., \& Rubenson, K. (2014). Adult learning typology: adult learning and returns to training project. Ottawa.

National Research and Development Centre for Adult Literacy and Numeracy. (2008). European adult learning glossary: level 2. Luxembourg.

Nesbit, T. (2005). Social class and adult education. New Directions for Adult and Continuing Education, 2005(106), 5-14.

OECD. (2007). Qualifications systems: bridges to lifelong learning. Paris: OECD.

OECD. (2008). Policy brief: ten steps to equity in education. Paris: OECD.

OECD. (2009a). Learning for Jobs: OECD policy review of vocational education and training: initial report. Paris.

OECD. (2010). Learning for jobs: synthesis report of the OECD reviews of vocational education and training. Paris.

OECD. (2013). Oecd skills outlook 2013 first results from the survey of adult skills. Paris: OECD.

OECD. (2016b). Skills Matter: further results from the Survey of Adult Skills, OECD Skills Studies. Paris.

Schuetze, H. G., \& Slowey, M. (2002). Participation and exclusion: a comparative analysis of non-traditional students and lifelong learners in higher education. Higher Education, 
44(3-4), 309-327.

Sheared, V., Johnson-Bailey, J., Colin, S. A. J., Peterson, E., \& Brookfield, S. D. (2010). The handbook of race and adult education: a resource for dialogue on racism. San Francisco: Jossey-Bass.

Unesco. (1984). Terminology of technical and vocational education. Geneva.

Unesco Institute for Lifelong Learning. (2016a). Recommendation on adult learning and education 2015. Hamburg.

Unesco UIS. (2011). International Standard Classification of Education (ISCED) 2011. Montreal.

Unesco-UNEVOC/NCVER. (2009). TVET glossary: some key terms. In R. Maclean \& D. Wilson (Eds.), International handbook of education for the changing world of work: volume 1. Dordrecht: Springer Science + Business Media.

Werquin, P. (2007). Terms, concepts and models for analysing the value of recognition programmes (No. EDU/EDPC(2007)24). Paris: OECD.

White, P. (2012). Modelling the 'learning divide': predicting participation in adult learning and future learning intentions 2002 to 2010. British Educational Research Journal, $38(1), 153-175$.

Wolbers, M. H. J. (2005). Initial and further education: substitutes or complements? Differences in continuing education and training over the life-course of European workers. International Review of Education, 51(5-6), 459-478.

Óhidy, A. (2008). Lifelong learning, Interpretations of an education policy in Europepp. 1 electronic text.). Available from http://site.ebrary.com/lib/aberdeenuniv/Doc?id=10257834 